Kristian Jensen*

\title{
Electronic Legal Deposit in the United Kingdom: Successes and Challenges of Transfer and Transformation
}

https://doi.org/10.1515/bfp-2021-0009

\begin{abstract}
The introduction of electronic legal deposit is arguably the greatest transformation which national libraries have undergone in our professional lifetimes. This article argues that many institutions have successfully implemented technical, structural, and cultural transformative change, while there is more to do, and challenges remain. When it comes to transfer however, the ability to give users meaningful access to the legal deposit collections, the picture is rather different: much good work is being done, but the transformative potential of electronic legal deposit has not been realised for our users. The article explores the broader cultural background specifically in the United Kingdom against which the relevant legislation was shaped to understand better what steps could be taken in the future to redress this imbalance.
\end{abstract}

Keywords: Electronic legal deposit; transfer; transformation; UK

\section{Das gesetzliche Pflichtexemplar elektronischer Publika- tionen in Großbritannien: Erfolge und Herausforderungen bei der Umsetzung und Transformation}

Zusammenfassung: Die Einführung des gesetzlichen Pflichtexemplars elektronischer Publikationen gehört vermutlich zu den größten Veränderungen, die Nationalbibliotheken während meines Berufslebens aufgegriffen haben. Der vorliegende Artikel legt dar, dass viele Institutionen die technische, strukturelle und kulturelle Transformation erfolgreich umgesetzt haben. Doch der Prozess ist noch nicht zu Ende; weitere Herausforderungen stehen an. Denn wenn Nutzer^innen Zugänge zu Sammlungen der gesetzlichen Pflichtexemplare für Übergaben zur Verfügung gestellt werden, vermittelt sich der Eindruck, dass schon viel geleistet wurde, aber die Nutzungspotenziale elektronischer Pflichtexemplare noch nicht in vollem Umfang verfügbar sind. Der Artikel zeigt den breiteren, kulturellen - speziell britischen - Hintergrund auf und wie

*Corresponding author: Kristian Jensen,

kristian.jensenhome@gmail.com die rechtlichen Rahmenbedingungen gestaltet wurden. So ist besser $\mathrm{zu}$ verstehen, welche weiteren Schritte noch zu gehen sind, um die Nutzung gesetzlicher Pflichtexemplare zu verbessern.

Schlüsselwörter: Gesetzliches Pflichtexemplar; elektronische Publikationen; Transformationsprozess; Großbritannien

The introduction of electronic legal deposit is arguably the greatest transformation which national libraries have undergone in our professional lifetimes. This article argues that many institutions have successfully implemented technical, structural, and cultural transformative change, while there is more to do, and challenges remain. When it comes to transfer however, the ability to give users meaningful access to the legal deposit collections, the picture is rather different: much good work is being done, but the transformative potential of electronic legal deposit has not been realised for our users. The article explores the broader cultural background specifically in the United Kingdom against which the relevant legislation was shaped to understand better what steps could be taken in the future to redress this imbalance.

In 2003 the Parliament of the United Kingdom passed the Legal Deposit Libraries Act, the first act which was primarily concerned with legal deposit. ${ }^{1}$ Until then legal deposit provisions had been part of legislation which was primarily focused on copyright.

Various acts, from Queen Anne's Act for the Encouragement of Learning' of $1710^{2}$ to the Copyright Act of

1 Legal Deposit Libraries Act 2003; Enacted 31 October 2003. https:// www.legislation.gov.uk/ukpga/2003/28/contents.

2 Public General Acts. 1709-1710. 8 \& 9 Anne c.19. An Act for the Encouragement of Learning, by Vesting the Copies of Printed Books in the Authors or Purchasers of Copies, during the Times therein mentioned. London: printed by the assigns of Thomas Newcomb, and Henry Hills, deceas'd; printers to the Queens most excellent Majesty, 1710. A transcription of the text is available at https://avalon.law.yal e.edu/18th_century/anne_1710.asp. 
$1911^{3}$ aimed to enable publishers to claim copyright. Briefly speaking, in the early acts they registered publications for copyright by depositing them. Under these acts, legal deposit can be seen as a regulatory burden but one which is necessary for publishers to obtain a major benefit, the protection of their copyright. The Copyright Act 1911 removed the need to register for copyright reasons but maintained the requirement to deposit as an integral part of the Copyright Act.

The 2003 Act caught up with reality. In the course of the twentieth century copyright in published works had become increasingly dissociated from legal deposit, and only a few years earlier the Copyright, Designs and Patents Act $1988^{4}$ had established copyright with no reference to legal deposit, not even to the 1911 Act. That does not mean that there are no impacts of copyright on legal deposit and vice versa, far from it. But it was by then explicit that the motivation for continuing legal deposit and for extending it to electronic publications had nothing to do with ensuring copyright for publishers or authors. Those protective of the interests of right holders no longer derived any direct benefit from the obligations imposed on them by the act, but only an obligation to deposit. Under these conditions, legal deposit can be seen as an exception to copyright and is indeed often seen as such, especially in the Guidance from Government on its implementation, where it is explicit that the legislation, rightly or wrongly, is seen as a burden on business which the regulations seek to minimise.

The act had no legal force until regulations had been agreed which would govern its implementation. The slow work on this began in 2003. The complex process of arriving at the regulations has been well described and contextualised by my former colleagues Richard Gibby and Caroline Brazier in a comprehensive article from 2012, ${ }^{5}$ just before the Regulations were actually implemented in 2013. ${ }^{6}$ The Regulations were followed up by guidance issued by government on the understanding of the regulations. ${ }^{7}$ With seven years of actual implementation of be-

3 Copyright Act 1911. 1911 Chapter. An Act to amend and consolidate the Law relating to Copyright. $16^{\text {th }}$ December 1911, available at http s://www.legislation.gov.uk/ukpga/1911/46/pdfs/ukpga_19110046_e n.pdf.

4 Copyright, Designs and Patents Act 1988. 1988 Chapter 48. An Act to restate the law of copyright ... [15th November 1988], available at ht tps://www.legislation.gov.uk/ukpga/1988/48/enacted.

5 Gibby and Brazier (2012).

6 The Legal Deposit Libraries (Non-Print Works) Regulations 2013, available at https://www.legislation.gov.uk/uksi/2013/777/contents/ made.

7 Department of Culture Media and Sport, Guidance on the Legal Deposit Libraries (Non-Print Works) Regulations 2013, available at hind us, this contribution therefore seeks to take a further look specifically at how the broad political environment shaped the legislation

The process of creating the regulations relied on the various stakeholders themselves creating a position which was acceptable to all affected parties, not least the legal deposit libraries and the publishing industry, including notably the newspaper industry. Gibby and Brazier have accounted for how the disparity in resources and political influence of the different groups meant that this often worked differently in reality from the formal process which was set out. The newspaper industry is powerful and some of the large news publishers, including that owned by Rupert Murdoch, are felt to be very important for ensuring popular approval of the government. The relationship is encapsulated in the headlines of the Murdoch owned tabloid newspaper "The Sun" on Saturday 11 April 1992, the day after the unexpected Conservative victory in parliamentary elections, "Its' the Sun Wot Won It". ${ }^{8}$

This work took place when the publishing industry was faced with the same radical upheaval as libraries, an uprooting of their existing business models as new ways of creating and of accessing content continuously emerged. For publishers it was unclear if there were also new ways of monetising content. There was and is an understandable anxiety about a lack of clarity of what could be monetised and about how it could be monetised. For businesses with long-established business models, it is hard to get to grips with a state of constant flux, where there may not be one route to profitability, but numerous different concurrent and - importantly - impermanent ways.

Simultaneously, the work towards regulations happened in an environment where an increasingly significant part of the political spectrum perceived state engagement with the free market was seen as exclusively negative - as interference.

The further political views moved towards economic liberalism, the greater the hostility to regulation. In that period we heard repeated calls to get rid of that which is called "red tape" - a derogatory term for regulation, the metaphor being derived from the red ribbons used previously used for tying up government papers. Phrases like "bonfire of regulations" or "bonfire of red tape" were and are frequently used by some politicians and by the parts of

https://assets.publishing.service.gov.uk/government/uploads/syste m/uploads/attachment_data/file/182339/NPLD_Guidance_April_20 13.pdf.

8 For an analysis of this relationship see Reeves et al. (2016). 


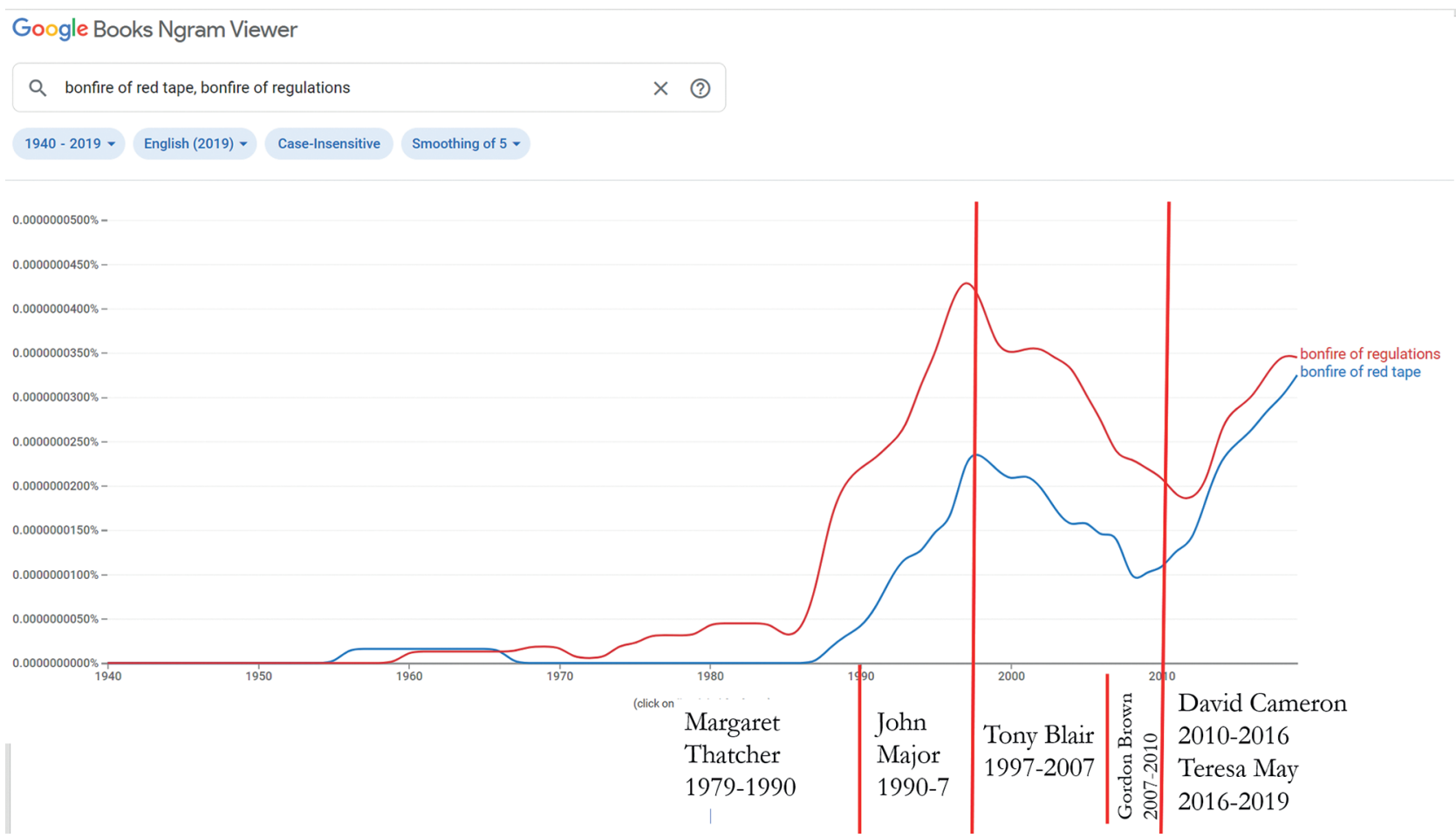

Fig. 1: Google Books N-gram viewer

the press which support them. It is possible that it is only with the British distance from events in Europe during the twentieth century that it is possible to use with such lack of restraint a metaphor about the burning of documentation. The phrase "red tape" can be seen as an expression of a subjective, negative perception of regulation as essentially detrimental to the profitable running of business. ${ }^{9}$ The attitude was well if critically captured by Martin Sandbu: "Yet the public debate on economic policy too often remains stuck in the simplistic understanding of product regulation, where it is almost axiomatically se as an economic cost paid for some non-economic political objective (or for detractors, a cost paid for no desirable objective at all. Hence the promise, seen in particular on the right of the political spectrum in the UK and the US, that deregulation will 'free' business and unleash its restrained productivity potential." 10

In this perspective one can see the approach of parts of the publishing industry as one which sought to contain the damaging impact of the powers of an overweening state by limiting the impact of legislation by seeking regulations which would focus on regulating the Legal Deposit Li-

9 See for instance the analysis based on extensive surveys of attitudes by Pandey and Scott (2002).

10 Sandbu (2018). braries rather than regulating the ways in which publishers should deposit.

Some of the governmental processes, mentioned by Gibby and Brazier, point to an explicit hostility in the government to the notion of regulation. They also pointed to the ability of the publishing industry to lobby government during the creation of the regulations. It is probably of equal importance that arguments against regulation were easily heard by senior decision makers as they confirmed some of their deeply held beliefs.

On the other hand, one may consider regulation as one of the tools available for governments to ensure a balance between opposing interests, often economic interests, balanced against wider, often less easily definable benefits, such as safety at work, building regulations, food standards, the protection of the environment, open commercial competition, or the economic and societal benefits from public access to information. In this perspective, held by a significant part of the political spectrum, but currently one with less impact, regulation and effective enforcement of regulation can be seen as a tool which seeks to strengthen the interests of the less powerful against those of the more powerful with their greater capacity for political influence. In this perspective the reduction of regulation and a concomitant reduction in the resources of bodies responsible for their enforcement are held responsible for structural problems such as major disasters 
such as the fire in of the Grenfell Tower in 2017 in which seventy-two people died. ${ }^{11}$

In their analysis of the attitudes of entrepreneurs to regulations Kaufmann et al. ${ }^{12}$ have explored the correlation of the perception of regulation as "red tape" with a number of societal attitudes and have perhaps unsurprisingly found for instance that regulation is more often perceived negatively, that is as "red tape". Perhaps not surprisingly, they found that a hostility to "red tape" was strongly positively correlated with politically conservative views of individual entrepreneurs, but also with a general conservative trend in their countries, and strongly positively correlated with a belief in the responsibility of individual for their own wellbeing rather than a more collectivist view of society, "so that external rules are more quickly perceived as red tape in countries that are more individualistic in nature" no matter whether these "rules are effective or meet valid objectives.'

The Google Books N-gram view from in Figure 1 shows the frequency in percent of the occurrence in the corpus digitised by Google of the phrases "bonfire of regulations" and "bonfire of red tape". I have plotted the UK prime ministers onto the timeline. Much can be said about this NGram and the immediate and mediate causes for the frequency of use of the phrase, but it gives a strong visualisation of the political polarisation of the very notion of regulation. We act in a polarised political environment where the discussion seems less to be about how we should regulate. Instead it seems to be about whether there should be regulations at all.

This is a very high-level, generic view of the political environment in which the Legal Deposit Libraries Act was passed, and in which the next steps had to be taken, to implement the Act through associated regulation.

This may be part of the explanation why the regulations were not finally implemented until implemented in 2013: legal deposit of digital publications only became possible ten years after the act to ensure this was passed by Parliament. Ten years is a very long time in terms of the development of digital. While support of legal deposit in the abstract remains non-partisan in the United Kingdom, the polarisation around the nature of regulation had a big impact on how the legislation was transformed to practice.

The British Library Act of 1972 makes no reference to the then still valid Copyright Act of 1911. In fact, I am not sure if there was any legal basis for the British Library to be

11 See for instance Clark (2017) blaming the fire on excessive red tape and Poole (2017).

12 Kaufmann et al. (2018). in receipt of legal deposit of physical items between 1973 and 2003.

The British Library Act has two generic statements about the purpose of the British Library It shall operate "as a national centre for reference, study and bibliographical and other information services, in relation both to scientific and technological matters and to the humanities" and it shall make its services "available in particular to institutions of education and learning, other libraries and industry". The Legal Deposit Libraries Act 2003 in turn makes no reference to the British Library Act 1972. No do the regulations, although the purpose of legal deposit if briefly referenced in the governmental guidelines. In other words, the two main acts of Parliament which affect the UK's national library have no explicit linkage. I believe that this lack of joining up has had a significant impact on the British Library's ability to meet its obligations under the 1972 Act.

In this context it is important that the Legal Deposit Libraries Act 2003 Act had formalised the decoupling of the obligation to deposit from the benefits which may flow from it. The wider societal benefits and the indirect benefits to authors and to the publishing industry were not given strong formal expression anywhere, which made it more difficult for arguments around public benefit to be made and to be heard. The case for the public good presumably underlying the primary legislation was not made by government: It was left to the legal deposit libraries to make this case to persuade government of its relevance.

The 1911 Copyright Act focused its section 15 on the duties of publishers to deposit. It has no section on obligations of the Libraries, nor on restrictions in their ability to make the legal deposit material available or on how it should be used. By contrast the Legal Deposit Libraries Act and the regulations set out very clearly what uses are permitted. For the avoidance of any misunderstanding, the ministerial guidelines spell it out, saying "These Guidelines are deliberately restrictive" when it comes to permitting use of the legal deposit material, and it says: "Only those activities which are specifically permitted in the regulations may be carried out in relation to the deposited non-print works." We are not used to seeing a narrow range of activities being declared legal. Rather one expects legislation to set out what is illegal, on the assumption that activities which are not illegal are permitted.

The guidelines are also clear that this approach was chosen to protect yet not identified ways in which rightsowners might in the future monetise their publications. This is further backed up by a provision, which in certain areas extends the restrictions imposed on the use of legal 
deposit materials beyond the duration of copyright. This has been described as "perpetual copyright".

In practice the regulations of use have imposed on researchers the same ways of working with digital publications as they typically used with printed publications.

The Google N-gram viewer, used above, is an example of a fairly basic digital examination of a corpus. This type of corpus level examination is one example of many which would not be permitted using the UK electronic legal deposit collections. Contemporary research methods may not be applied to this body of material.

Material which was published as freely available, even material published explicitly under creative commons provisions may not be made available outside the physical premises of the legal deposit institutions. This is true first and foremost of the magnificent web archive.

The legal deposit collections constitute a form of collection unparalleled by any other cultural institution. The absence of selectivity gives breath-taking breadth of coverage. No other collection of anything is so broadly comprehensive of what we can generically describe as the intellectual activity of the nation. And it also goes deep. We have lived through a remarkable year of a major pandemic, leading to radical social transformation, and marked by radical expressions of a need for equality and inclusion by Black people. Black Lives Matters has been, and I believe will remain a watershed for British society and for its institutions. The digital legal deposit collections, not least through the web archive, document this in a way which physical legal deposit, magnificent as it was, cannot match. There are gaps and shortcoming - for instance recently Richard Ovenden pointed to the importance, not least for public accountability, of privately-communicated social media where messages have a short life. ${ }^{13}$ Nothing is perfect, but the breadth and depth of the electronic legal deposit collections are astonishing.

The legal deposit libraries spend significant proportions of their resources on creating these magnificent collections of unparalleled diversity and inclusivity, in a period where this is ever more important. But we make them available, if at all, in ways which the majority of the nation would find baffling if they knew, and which makes little sense to our traditional researcher user base who know about the collection and its importance.

This echoes findings in studies of regulations, that the efficacy of regulations and their ability to support the stated aim are significant factors in gaining support for

13 Ovenden (2020). them, rather than seeing them rejected as "red tape". ${ }^{14}$ Indeed the definition of "red tape" proposed by three prominent students of public administration is "rules, regulations, and procedures that remain in force and entail a compliance burden but have no efficacy for the rules' functional object”. ${ }^{15}$

It could be argued that the regulatory framework around electronic legal deposit in the UK is neither efficacious nor enables the legal deposit libraries to fulfil the public-good aims which motivated the primary legislation. This disequilibrium poses several risks to the legal deposit collections and arguably to the longer terms justification for the institutions which hold them.

Within institutions it can be difficult to allocate resources to work which does not have a measurable impact over a reasonably short time scale and, with their many legitimate but competing priorities, it can be difficult for institutions to give visibility and priority to resources which have a public impact which is disproportionately small to their cost, and indeed to their potential. Institutions may find it more attractive to invest their resources elsewhere.

Issues of equality, diversity, and inclusion are ever higher on the agenda for the nation and for its institutions. Our legal deposit collections are by a very long distance the most diverse and most inclusive among the many national collections in the UK. None of the national museums have contemporary collections to match legal deposit in size, scope, and inclusivity. The national governance structures of Britain have created parameters for the use of legal deposit which make them extraordinarily hard to use for current researchers, and make it difficult for the British Library to use its most obviously national collection to fulfil its obligation as a national institution as set out in the British Library Act.

There is a real risk that we will lose relevance and support if we cannot meet reasonable expectations, informed by a contemporary digital environment, contemporary research practices, and by contemporary social expectations. This is compounded by a risk of loss of support from a cultural, political environment where the standing of public institutions as providers of a public good is being questioned, not least in a period where we must expect further significant financial retrenchment.

14 Chartered Institute of Personnel and Development, Employment regulation in the UK: burden or benefit? Survey report May 2017, available at https://www.cipd.co.uk/Images/employment-regulatio n-in-the-UK_2017-burden-or-benefit_tcm18-21622.pdf and Kaufmann et al. (2018).

15 Rainey et al. (1995). 
The British Library and other national libraries have achieved profound transformation in the last two decades, and are organisationally, culturally, and technically broadly able to deal with the vast majority of the nation's intellectual output. It is imperative that we work closely with our users to identify ways in which the current regulations can be modified so that national legislation can catch up with the transformation which content creation, research and indeed national libraries have undergone.

\section{References}

Clark, Ross (2017): Why are some on the Left claiming a 'bonfire on red tape' led to Grenfell Tower? In: The Spectator, 5 July, 20117. Available at https://www.spectator.co.uk/article/why-are-som e-on-the-left-claiming-a-bonfire-on-red-tape-led-to-grenfell-tow er-.

Gibby, Richard; Brazier, Caroline (2012): Observations on the development of non-print legal deposit in the UK. In: Library Review, 61 (5). Available at https://www.emerald.com/insight/publica tion/issn/0024-2535/vol/61/iss/5.

Kaufmann, W; Hooghiemstra, R; Feeney, MK (2018): Formal institutions, informal institutions, and red tape: A comparative study. In: Public Administration, 96, 386-403. Available at https://doi. org/10.1111/padm.12397.

Ovenden, Richard (2020): Ephemeral messages remove scrutiny from government. In: The Financial Times, 13 October, 2020. Available at https://www.ft.com/content/d7f10eb2-895e-4a7e-9522-2d3 65e7a205b.
Pandey, S. K.; Scott, P. G. (2002): Red tape: A review and assessment of concepts and measures. In: Journal of Public Administration Research and Theory, 12, 553-80.

Poole, Steve (2017): ‘Deadlier than terrorism' - the right's fatal obsession with red tape. In: The Guardian, 20 June, 2017. Available at https://www.theguardian.com/politics/2017/jun/20/deadlierthan-terrorism-right-fatal-obsession-red-tape-deregulation-gre nfell-tower.

Rainey, H.; Pandey, S.; Bozeman, B. (1995): Research Note: Public and Private Managers' Perceptions of Red Tape. In: Public Administration Review, 55 (6), 567-74.

Reeves, Aaron; McKee, Martin; Stuckler, David (2016): 'It‘s The Sun Wot Won It': Evidence of media influence on political attitudes and voting from a UK quasi-natural experiment. In: Social Science Research, 56, 44-57. Available at https://doi.org/10.10 16/j.ssresearch.2015.11.002.

Sandbu, Martin (2018): Rethinking Regulation. In: Financial Times, 20 April, 2018. Available at https://www.ft.com/content/06e8b d72-4458-11e8-803a-295c97e6fd0b.

\section{Kristian Jensen}

Consortium of European Research Libraries

40 Bowling Green Lane

UK-London EC1R

Great Britain

kristian.jensenhome@gmail.com 